\title{
Cooling of soybean seeds and physiological quality during storage ${ }^{1}$
}

\author{
Fabiano Carlos Ferreira ${ }^{2}$, Francisco Amaral Villela ${ }^{3}$, \\ Géri Eduardo Meneghello ${ }^{3}$, Vanessa Nogueira Soares ${ }^{3^{*}}$
}

\begin{abstract}
The aim of this study was to evaluate the physiological quality of soybean seeds submitted or not to dynamic cooling, and kept in cold storage (CS) and non-cold storage (NCS). A soybean seeds lot, variety M7639RR, was divided into two parts, and each one was subdivided into three parts that were subjected to one of these cooling procedure: seeds without cooling (SWC), dynamic cooling at $17{ }^{\circ} \mathrm{C}$ (SC17), and dynamic cooling at $13{ }^{\circ} \mathrm{C}$ (SC13). Seeds were kept in CS and NCS at $20^{\circ} \mathrm{C}$. Samples were collected at six times $(0,45,90,135,180$ and 225 days $)$, and then submitted to germination, tetrazolium, accelerated aging and seedling emergence tests. Dynamic artificial cooling at $13{ }^{\circ} \mathrm{C}$ followed by maintenance at $20^{\circ} \mathrm{C}$ ensured the preservation of physiological quality of soybean seeds for up to 225 days. The vigor of the soybean seeds subjected to dynamic cooling at $13{ }^{\circ} \mathrm{C}$ was better preserved than that of the non-cooled or of the cooled at $17{ }^{\circ} \mathrm{C}$ ones and kept in NCS for 225 days. $\mathrm{CS}$ at $20^{\circ} \mathrm{C}$ contributed to the preservation of the physiological quality of the soybean seeds, regardless of whether or not they were submitted to the dynamic procedure.
\end{abstract}

Index terms: Glycine max, artificial cooling, germination, vigor

\section{Resfriamento de sementes de soja e qualidade fisiológica no armazenamento}

\begin{abstract}
RESUMO - O objetivo do trabalho foi avaliar a qualidade fisiológica de sementes de soja submetidas ou não ao resfriamento dinâmico e mantidas em armazém resfriado (AR) e não resfriado (ANR). Um lote de sementes de soja, variedade M7639RR, foi dividido em duas partes, que foram subdivididas em três partes, cada uma submetida a um procedimento de resfriamento: sementes não resfriadas (SNRE), resfriamento dinâmico a $17{ }^{\circ} \mathrm{C}$ (SRE17) e a $13{ }^{\circ} \mathrm{C}$ (SRE13). As sementes foram mantidas em um ANR e em AR a $20^{\circ} \mathrm{C}$. Foram coletadas amostras em seis momentos $(0,45,90,135,180$ e 225 dias), e as sementes foram submetidas aos testes de germinação, tetrazólio, envelhecimento acelerado e emergência de plântulas em canteiro. O resfriamento dinâmico artificial a $13{ }^{\circ} \mathrm{C}$ seguido de manutenção em AR a $20{ }^{\circ} \mathrm{C}$ assegurou a preservação da qualidade fisiológica de sementes de soja por até 225 dias. Sementes de soja submetidas ao resfriamento dinâmico a $13{ }^{\circ} \mathrm{C}$ preservam melhor o vigor, comparativamente às não resfriadas ou resfriadas a $17^{\circ} \mathrm{C}$ e mantidas em $\mathrm{ANR}$ por 225 dias. $\mathrm{O} \mathrm{AR}$ a $20^{\circ} \mathrm{C}$ contribui para preservação da qualidade fisiológica da semente de soja, independentemente de a semente ser ou não submetida ao procedimento dinâmico.
\end{abstract}

Termos para indexação: Glycine max, resfriamento artificial, germinação, vigor.

\section{Introduction}

Brazilian production of soybean (Glycine max (L.) Merril) is among the largest in the world, and it reached approximately 106 million tons in 2015/2016 harvest (CONAB, 2016). To keep the production of this commodity at this level or even higher, seeds are the most important inputs used by farmers. Through it, producers have access to the most recent technologies available in the sector, thus it is essential that high quality seeds be produced and commercialized.

In tropical climate conditions, like important soybean producer regions in Brazil, the adequate storage is fundamental to preserve the physiological quality of soybean seeds (Zuchi et al., 2013). As said by Villela and Menezes (2009), the main goals of the storage are to preserve seeds viability and vigor from one harvest to another, and to reduce the deterioration

\footnotetext{
${ }^{1}$ Submitted on $03 / 24 / 2017$. Accepted for publication on 10/06/2017.

${ }^{2}$ Sementes Petrovina, 78700-150 - Rondonópolis, MT, Brasil.

${ }^{3}$ Departamento de Fitotecnia ,Universidade Federal de Pelotas, Caixa Postal 354, 96001-970 - Pelotas, RS, Brasil.

*Corresponding author < vnsoares@gmail.com>
} 
speed. The deterioration process is inevitable, and can only be delayed (Cardoso et al., 2012).

The association between temperature and humidity influence the longevity of seeds during storage. Harrington (1959) affirmed that at this stage, for every decrease of $5,5^{\circ} \mathrm{C}$ in temperature, the longevity doubles. According to Villela and Menezes (2009) and Demito and Afonso (2009), the reduction of seeds temperature is a viable technic to preserve their physiological quality, since it reduces the metabolism.

Therefore, artificial cooling of seeds is an important tool in controlling temperature and air relative humidity, which allows a reduction in the consumption of seeds reserve substances by pathogens or by their own respiration process. Artificial cooling of seeds is a technic of insufflation of air at 15 to $20^{\circ} \mathrm{C}$ and relative humidity of 55 to $60 \%$ (Villela and Menezes, 2009). This process can be done during the bagging and/or during the storage period (Demito and Afonso, 2009). The technic revolutionized the storage of orthodox seeds, since it is possible to implement this system to large volumes of seeds.

Demito and Afonso (2009) observed that the physiological quality of artificially cooled soybean seeds was maintained for 140 days of storage, with a percentage of germination higher than the non-cooled ones. This result was attributed to the thermic stability of the seeds at the cooling temperature during storage.

When evaluating the physiological quality of three soybean cultivars submitted or not to dynamic cooling process, Zuchi et al. (2013) verified that the cooling only maintained the physiological quality of two of the cultivars. These authors suggested that more studies about artificial cooling of seeds are necessary. The aim of this work was to evaluate the physiological quality of soybean seeds submitted to dynamic cooling during storage.

\section{Material and Methods}

\section{Location of the experiment and plant material}

The experiment was installed at UBS Sementes Petrovina,

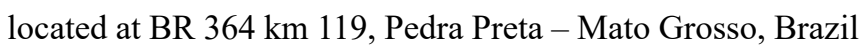
(latitude 16 $50^{\prime} 28.3^{\prime \prime} \mathrm{S}$, longitude $5^{\circ} 03^{\prime} 35.4^{\prime \prime} \mathrm{W}$ and altitude 734 meters), between March and October, 2014. A soybean seeds lot $(1.8000 \mathrm{~kg})$, cultivar of early cycle M7639RR, produced in 2013/2014 harvest, was used. Before packing, the lot was subdivided into three sublots to compose the cooling treatments of seeds. Each sublot was packed in six packs (big bags), made of interlaced polypropylene with $1,20 \times 1,00 \times$ $1,06 \mathrm{~m}$ dimensions and $1.000 \mathrm{~kg}$ capacity each.

\section{Cooling of the seeds}

At the moment of bagging, the first sublot was kept at room temperature of approximately $25{ }^{\circ} \mathrm{C}$, and the other two sublots were put inside cooling boxes, and submitted to dynamic cooling by a CoolSeed cooler, model PCS 120, with cooling capacity of $363.636 \mathrm{kcal} . \mathrm{h}^{-1}$ and potential of 35 tons per hour at $18^{\circ} \mathrm{C}$.

Two cooling boxes were used, with a static capacity of 15 tons each, to obtain the other sublots. The air was artificially chilled at $12{ }^{\circ} \mathrm{C}$, conducted at low velocity inside ventilation tubes and insufflated through the mass of seeds. As it was passing, the cold air exchanged heat and moisture with the seeds, which had their temperature reduced over the time. At the moment that the mass of seeds of one of the boxes reached $17{ }^{\circ} \mathrm{C}$, another sublot was packed. The third sublot was chilled and packed at $13{ }^{\circ} \mathrm{C}$, using the same procedure previously described. Consequently, there were three cooling procedures: $\mathrm{SC} 13$ (seeds cooled at $13{ }^{\circ} \mathrm{C}$ at packing); $\mathrm{SC} 17$ (seeds cooled at $17^{\circ} \mathrm{C}$ at packing) and SNC (seeds not cooled at packing).

\section{Storage of seeds}

The soybean seeds from each cooling procedure (SC13; SC17; SNC) were divided into two parts, each composed of three big bags that were kept in two warehouses for 225 days. One of the warehouses was cooled at $20^{\circ} \mathrm{C}(\mathrm{CS})$, whereas the other was not refrigerated (NCS).

The warehouses had dimensions of $06 \times 30 \times 154 \mathrm{~m}$, and static capacity of $27.720 \mathrm{~m}^{3}$. They were masonry built, with double-layered brick walls, cement floor and zinc roof covered by thermal coating, in order to reduce the heat flow from the outside. One of the warehouses had controlled temperature (CS), whereas the environmental conditions during storage remained uncontrolled on the other (NCS).

Monitoring of temperature and relative humidity in the warehouses

In both warehouses, the temperature $\left(\mathrm{T}^{\circ} \mathrm{C}\right)$ and the relative humidity $(\mathrm{RH} \%)$ of the internal environment, and the temperature $\left(\mathrm{T}^{\circ} \mathrm{C}\right)$ of the seeds mass were monitored. A data logger DH $175 \mathrm{~T} 2$ was used to read the internal $\mathrm{T}^{\circ} \mathrm{C}$ and $\mathrm{RH} \%$ of the warehouse every hour. To measure the temperature of the seed mass, a DH 175 T2 data logger was adapted with a probe, which remained inserted into the center of a big bag of each treatment during the entire storage period. The data were recorded in the memory of the data logger device and read every fifteen days. 


\section{Seeds sampling}

The samples to evaluate the quality of the soybean seeds were obtained at $0,45,90,135,180$ and 225 storage days, and three replications per treatment were collected.

In the laboratory, the samples were separated and identified according to company's standard procedures. Each sample was homogenized in a Boerner homogenizer, and the following analyses were carried out:

Germination test: It was performed in eight subreplications of fifty seeds per sample. They were placed on towel paper rolls, moistened with 2.5 times the dry paper mass, and then put inside germination chambers at constant temperature of $25{ }^{\circ} \mathrm{C}$. The counts were performed five and eight days after sowing, so it was calculated the percentage of normal seedlings according to Brasil (2009).

Accelerated aging: It was performed in 200 seeds per replication, divided into four sub-replications of fifty seeds per sample. The seeds were placed in metal screens, which were fixed in transparent plastic boxes $(11 \times 11 \times 3.5 \mathrm{~cm})$ containing $40 \mathrm{~mL}$ of distilled water in the bottom. The boxes were kept in BOD incubator at $41{ }^{\circ} \mathrm{C}$ for $48 \mathrm{~h}$. After this period, the paper roll germination test was carried out, as previously described for the germination test. At the end of the fifth day after sowing, the percentages of normal seedlings were computed.

Tetrazolium test: It was carried out in four replications of fifty seeds previously placed on towel paper, moistened with water equivalent to 2.5 times its weight. The treatments were kept in these conditions for $16 \mathrm{~h}$ at $25{ }^{\circ} \mathrm{C}$. Afterwards, the seeds were deposited in plastic cups of $50 \mathrm{~mL}$, and totally submerged in $0.08 \%$ tetrazolium salt solution. They remained at $40{ }^{\circ} \mathrm{C}$ for two hours, so the staining could occur and allow the data interpretation (Costa et al., 2007). The results for vigor and viability of the seeds were computed.

Emergence of seedlings in seedbed: It was performed in four sub-replications of fifty seeds per sample. The seeds were distributed equidistantly from one another in lines on the seedbed, inside furrows with $1.5 \mathrm{~m}$ long and $0.03 \mathrm{~m}$ deep, and a space of $0.05 \mathrm{~m}$ between them. Counts were performed eight days after sowing, and the percentages of emerging seedlings were computed.

Experimental design: The experiment was carried out in randomized blocks design, and subdivided plots, with a $3 \times 2$ factorial in the plot. This means that there were three cooling procedures (SC13, SC17 and $\mathrm{SNC}$ ) and two storage conditions (CS and NCS) in the plot. The storage periods (0, $45,90,135,180$ and 225 days) were the sub-plots. The data expressed in percentage were submitted to the transformation, where $\mathrm{x}$ is the percentage value of each transformed variable. The analysis of variance (ANOVA) was done, in order to obtain the normality of the data and interpret them. In the case of significance, the data from cooling procedures and storage conditions were subjected to polynomial regression analysis.

\section{Results and Discussion}

The mean storage temperature in the unrefrigerated warehouse (NCS) was $24.6{ }^{\circ} \mathrm{C}$, while it was $21.1{ }^{\circ} \mathrm{C}$ in the refrigerated one (CS) (Figure 1). In the $\mathrm{CS}$, the temperature of the seed mass reached the equilibrium around the $23^{\text {rd }}$ day, at an average of $23^{\circ} \mathrm{C}$; by the $50^{\text {th }}$, this value decreased to 21 ${ }^{\circ} \mathrm{C}$ (Figure 1A). Therefore, cooling at the moment of packing, either to $13{ }^{\circ} \mathrm{C}$ or $17{ }^{\circ} \mathrm{C}$, was an alternative to maintain mild temperatures in the seed mass during the first days of storage, even when the external temperatures oscillated. In the treatments, there was an average reduction of $0.4{ }^{\circ} \mathrm{C}$ and $0.27{ }^{\circ} \mathrm{C}$ per day, respectively, until the equilibrium with the room temperature was reached. In the unrefrigerated warehouse (NCS), the average temperature was $24.6{ }^{\circ} \mathrm{C}$ (Figure 1B). There were fluctuations during the 225 days, and the maximum temperature got to $29^{\circ} \mathrm{C}$, while the minimum was around $10{ }^{\circ} \mathrm{C}$. Despite these environmental oscillations, the seed mass of the treatments achieved equilibrium close to the 19th day and, from this point on, the NCS started to show the same behavior as the refrigerated storage (CS).

The relative humidity $(\mathrm{RH})$ inside the $\mathrm{CS}$ oscillated between 60 and $68 \%$, which indicates certain stability in this warehouse (Figure 2). Inside the NCS, the RH oscillated between $63 \%$ and $75 \%$, until the $135^{\text {th }}$ day. After this period, the RH started to decrease, and it reached $40 \%$ on the $165^{\text {th }}$ day, and $24 \%$ on the $200^{\text {th }}$ day. It remained at $50 \%$ by the end of the storage. In comparison to the NCS, the control of the temperature and the relative humidity in the CS allowed to maintain the seeds in more favorable conditions, thus guaranteeing a potential preservation of their longevity, and consequently a superior quality throughout the storage.

In the germination test, there was no significant interaction among the cooling procedures SC13, SC17 and $\mathrm{SNC}$ in each storage condition. However, there was a significant difference between the refrigerated (CS) and the non-refrigerated (NCS) environments, which was graphically expressed by polynomial regression, considering the mean of the treatments of each warehouse (Figure 3).

The seeds of all cooling procedure stored in the CS showed a less pronounced linear reduction of the physiological quality than those kept in the NCS. They began with $94 \%$ germination on the first day of storage, and ended with $91 \%$ 

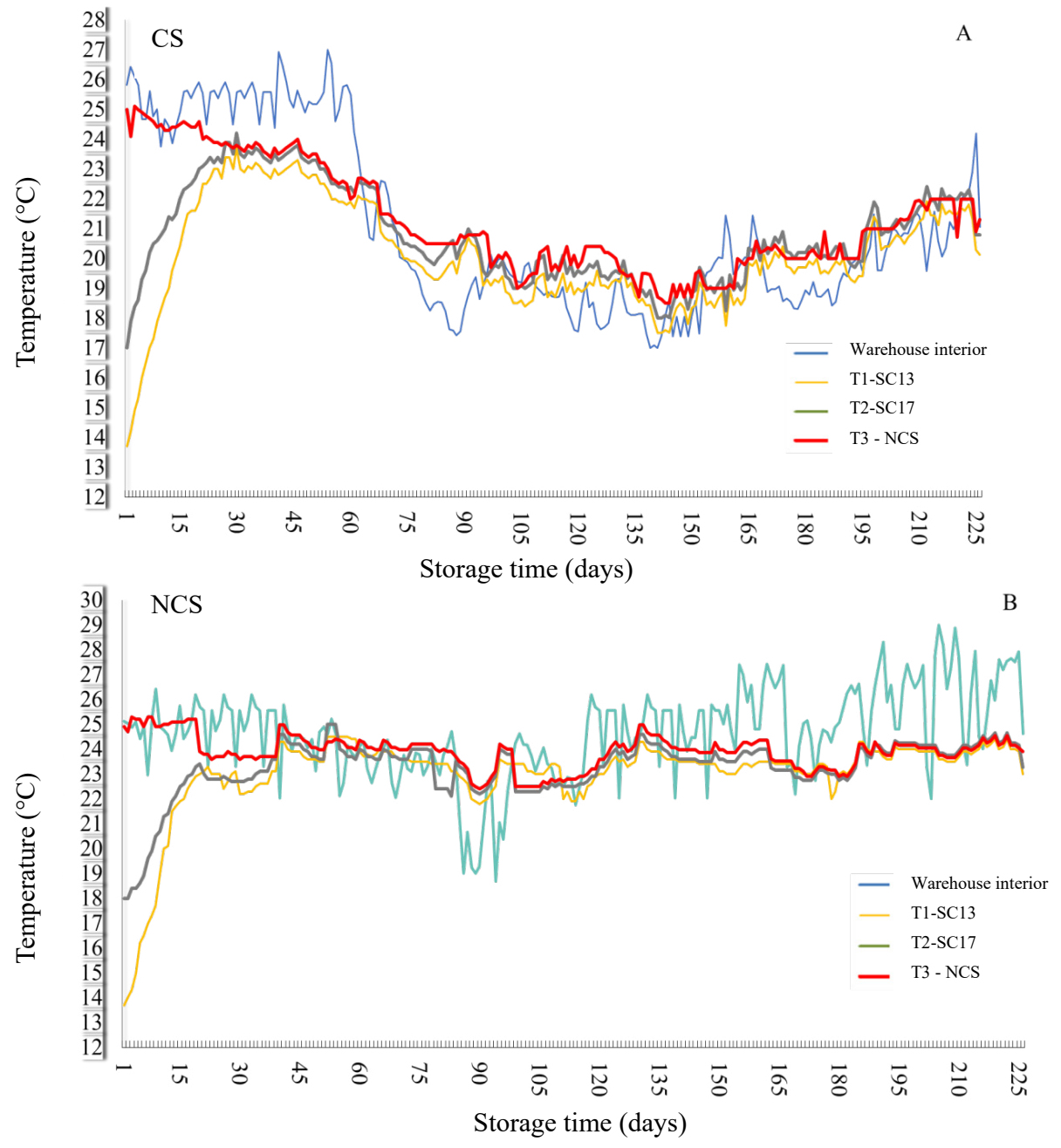

Figure 1. Daily temperature $\left({ }^{\circ} \mathrm{C}\right)$ of the seeds mass inside the cooled (CS) and the non-cooled (NCS) warehouses, throughout 225 of storage. Seeds were submitted to the cooling procedures T1-SC13 (seeds cooled at $13{ }^{\circ} \mathrm{C}$ at bagging), T2-SC17 (seeds cooled at $17^{\circ} \mathrm{C}$ at bagging) and T3-SNC (seeds not cooled at bagging).

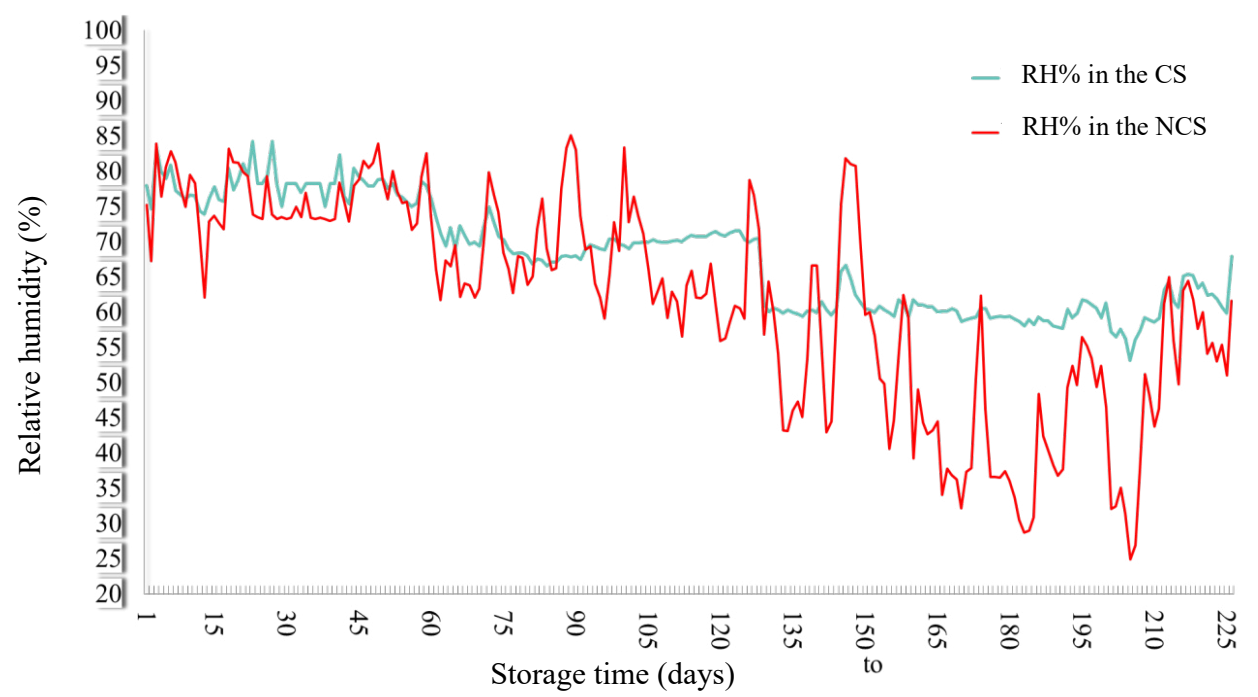

Figure 2. Relative humidity (\%) inside the cooled (CS) and non-cooled (NCS) warehouses, throughout 225 days of storage. 


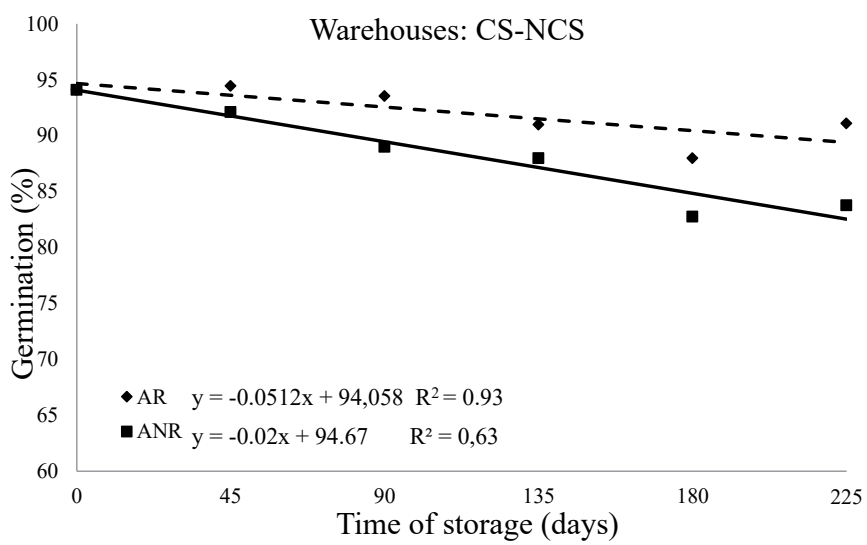

Figure 3. Germination of soybean seeds (\%) throughout 225 days of storage, in the cooled storage (CS) and (B) non-cooled storage (NCS). It was considered the mean of the cooling procedures $\mathrm{SC} 13$ (seeds cooled at $13{ }^{\circ} \mathrm{C}$ at bagging), $\mathrm{SC} 17$ (seeds cooled at $17^{\circ} \mathrm{C}$ at bagging) and SNC (seeds not cooled at bagging).

after 225 days, a decrease of three percentage points (pp) during storage. The seeds stored in the NCS also showed a linear decrease in germination, but it was more pronounced. The seeds began with $94 \%$ germination and, on the $225^{\text {th }}$ day of storage, they reached $84 \%$ germination, a reduction of 10 pp during storage.

By the end of the storage period, the difference between the CS and the NCS reached seven pp. These results indicated that the preservation of soybean seeds quality was better in the CS. Therefore, the main goal of the storage was reached, which was the preservation of seeds viability (Villela and Menezes, 2009) through temperature control, which slowed down the deterioration (Cardoso et al., 2012). In this occasion, however, the cooling of the seeds at the moment of bagging did not brought any substantial benefit in relation to the non-cooling.

The analysis of viability evaluated by the tetrazolium test did not detect a marked variation among the cooling procedures. In both warehouses, refrigerated and nonrefrigerated, the seeds submitted to the three cooling procedures behaved alike. The $\mathrm{SC} 13$ lot presented a quadratic adjustment, the $\mathrm{SC} 17$ a linear trend and the SNC showed no significant response.

The average viability reduction in the CS was four $\mathrm{pp}$ (Figure 4A), while it decreased seven pp in the NCS, in relation to the beginning of storage (Figure 4B). These results indicate once more that cooling soybean seeds during the storage contributes to maintain their physiologic quality. Despite these non-marked differences, negative effects in growing components may be noticed at the final culture stage. These, however, tend to attenuate as the plant grow (Schuch et al., 2009).

According to the vigor determined by the tetrazolium test (Figure 5), the cooling procedures exhibited similar results for both refrigerated and non-refrigerated warehouses, with similar trend lines throughout the storage.

In the $\mathrm{CS}$, the cooling procedures $\mathrm{SC} 17$ and SNC showed sharper reductions in vigor, expressed by quadratic functions, with a decline of 29 and 10 percentage points after 225 days of storage, respectively (Figure 5A). However, the cooling procedure $\mathrm{SC} 13$ presented a lower quality reduction, and the vigor had a maximum decrease of six percentage points. In this situation, the benefit of seed cooling at the moment of bagging is evident, emphasis given to the SC13 cooling procedure, which showed a superior seed performance in comparison to the SC17. These results agree with those found by Zuchi et al. (2013) and Demito and Afonso (2009), in which they observed that soybeans seeds subjected to cooling have maintained their physiological quality during storage for up to 120 and 140 days, respectively. It is worth noting that in all three cooling procedures and in the refrigerated warehouse,
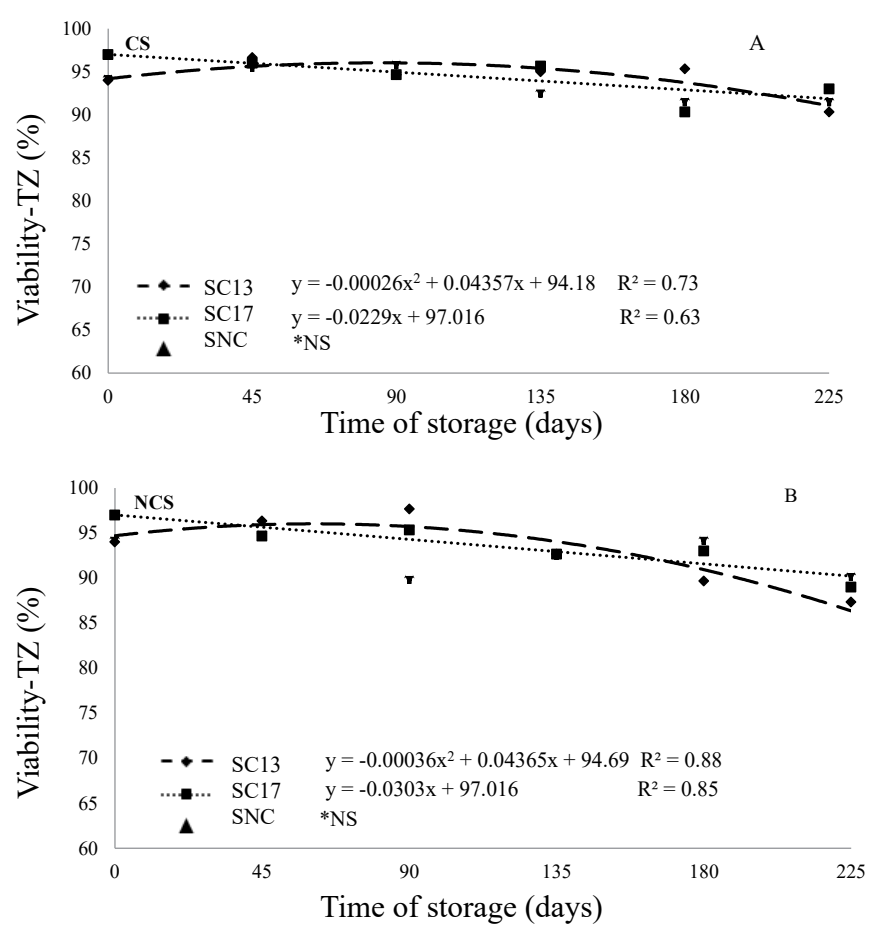

Figure 4. Viability of soybean seeds (\%) according to the tetrazolium test, throughout 225 days of storage in (A) cooled storage (CS) and (B) non-cooled storage (NCS). Seeds were submitted to dynamic cooling in three procedures: $\mathrm{SC} 13$ (seeds cooled at $13{ }^{\circ} \mathrm{C}$ at bagging); $\mathrm{SC} 17$ (seeds cooled at $17^{\circ} \mathrm{C}$ at bagging) and SNC (seeds not cooled at bagging). 
seeds presented vigor above $80 \%, 135$ days of storage later.

Despite the similar behavior in both warehouses, in the NCS the seeds of the three cooling processes presented a greater decrease in vigor (Figure 5B), compared to those stored in the CS. As for the comparisons among the procedures, it was verified that the seeds vigor decreased in all of them, and that in the $\mathrm{SC} 17$ procedure there was a 35 -percentage points reduction. Nevertheless, in the SC13 and SNC procedures, the decrease was $14 \mathrm{pp}$ throughout the storage period. When comparing the storage conditions, refrigerated and not, it is possible to confirm that the refrigerated warehouse kept the vigor of seeds at least five percentage points higher in all cooling procedures. This indicates that the CS favors the preservation of the physiological quality of soybean seeds.

Therefore, it is worth emphasizing the importance of using greater vigor seeds, since low vigor plants will have less solar capture conditions. High vigor plants have more competitive capacity during the crop cycle, and can be identified as dominant plants in the population, in contrast
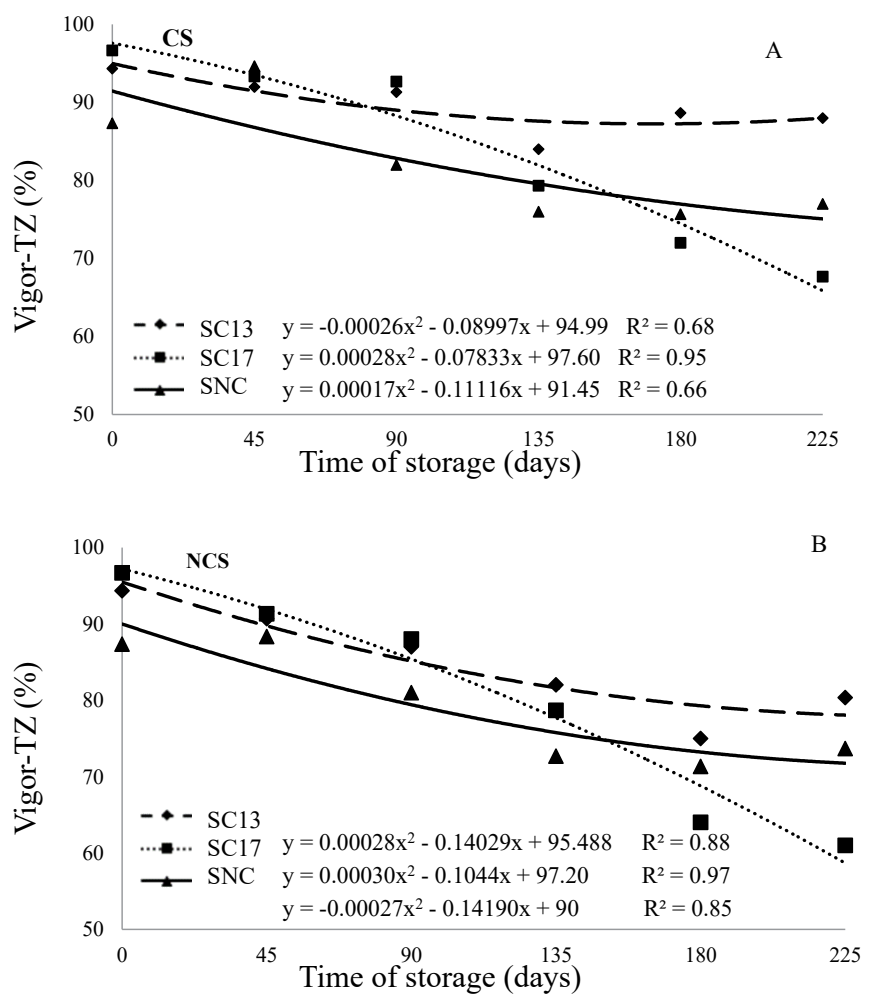

Figure 5. Vigor (\%) of soybean seeds according to the tetrazolium test, throughout 225 days of storage in (A) cooled storage (CS) and (B) non-cooled storage (NCS). Seeds were submitted to dynamic cooling in three procedures: SC13 (seeds cooled at $13{ }^{\circ} \mathrm{C}$ at bagging), $\mathrm{SC} 17$ (seeds cooled at $17{ }^{\circ} \mathrm{C}$ at bagging) and SNC (seeds not cooled at bagging). with the smaller plants, which have less capacity to gather resources (Cantarelli et al., 2015b)

The results of the accelerated aging test can be analyzed as another parameter of seeds physiological quality (Figure 6). In the CS, the seeds of all three cooling procedures showed responses that can be represented by quadratic trend curves. In this storage condition, there was an average vigor reduction of up to nine pp during the storage period (Figure 6).

In the NCS, there was difference among the cooling procedures. The SC13 showed a trend line similar to the CS, with 10-percentage points reduction in vigor during storage. However the decrease of vigor was more pronounced in the other procedures (Figure $6 \mathrm{~B}$ ). In the $\mathrm{SC} 17$, there was 18-pp difference between the initial vigor and its value after 225 days of storage. In the SNC procedure, the results varied, with a marked decline of $25 \mathrm{pp}$ in vigor by the $180^{\text {th }}$ day, and an overall 17-pp decrease, according to the last test performed at the end of the storage period (Figure 6B).

When the cooling procedures were compared under the
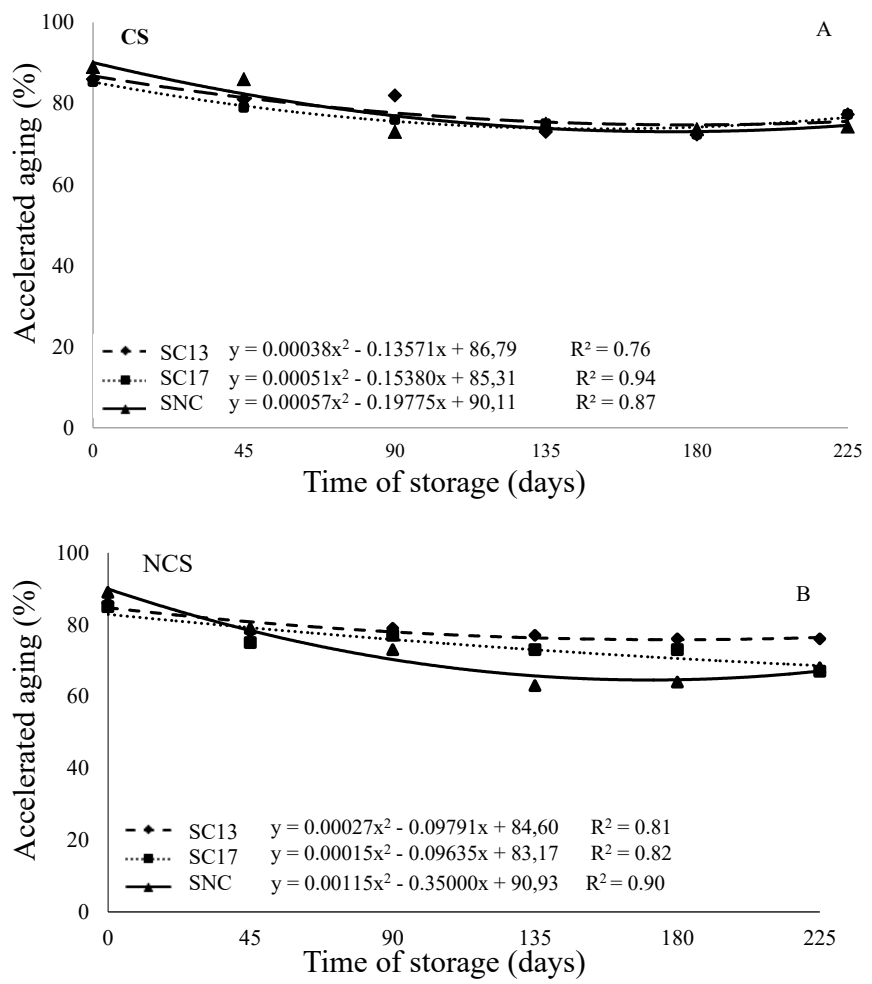

Figure 6. Accelerated aging (\%) of soybean seeds throughout 225 days of storage in (A) cooled storage (CS) and (B) non-cooled storage (NCS). Seeds were submitted to dynamic cooling in three procedures: SC13 (seeds cooled at $13{ }^{\circ} \mathrm{C}$ at bagging), SC17 (seeds cooled at $17^{\circ} \mathrm{C}$ at bagging), and SNC (seeds not cooled at bagging). 
storage conditions, the CS stood out positively once again, with $10 \mathrm{pp}$ more than the NCS, in the $\mathrm{SC} 17$ procedure. The accelerated aging test can be used to estimate seed longevity, which depends on the initial vigor and on the environment where they are stored (Baudet and Villela, 2012). In this work, seeds of all the cooling procedures presented satisfactory performance in the CS. However, in the NCS the reductions of vigor were more pronounced, which is why using artificial cooling throughout the storage period is recommended. The climate-controlled environment $\left(20^{\circ} \mathrm{C}\right)$ provides better conservation of the physiological quality of soybean seeds (Smaniotto et al., 2014). On the other hand, storage in an uncontrolled environment causes a greater reduction of the physiological potential of soybean seeds (Forti et al., 2010).

To confirm the results obtained in laboratory, the seeds were submitted to the emergence test in seedbeds (Figure 7). In the $\mathrm{CS}$, the $\mathrm{SC} 13$ procedure did not show a significant trend curve, whereas the $\mathrm{SC} 17$ and the SNC procedures presented reductions in vigor, with a decrease of nine and five $\mathrm{pp}$
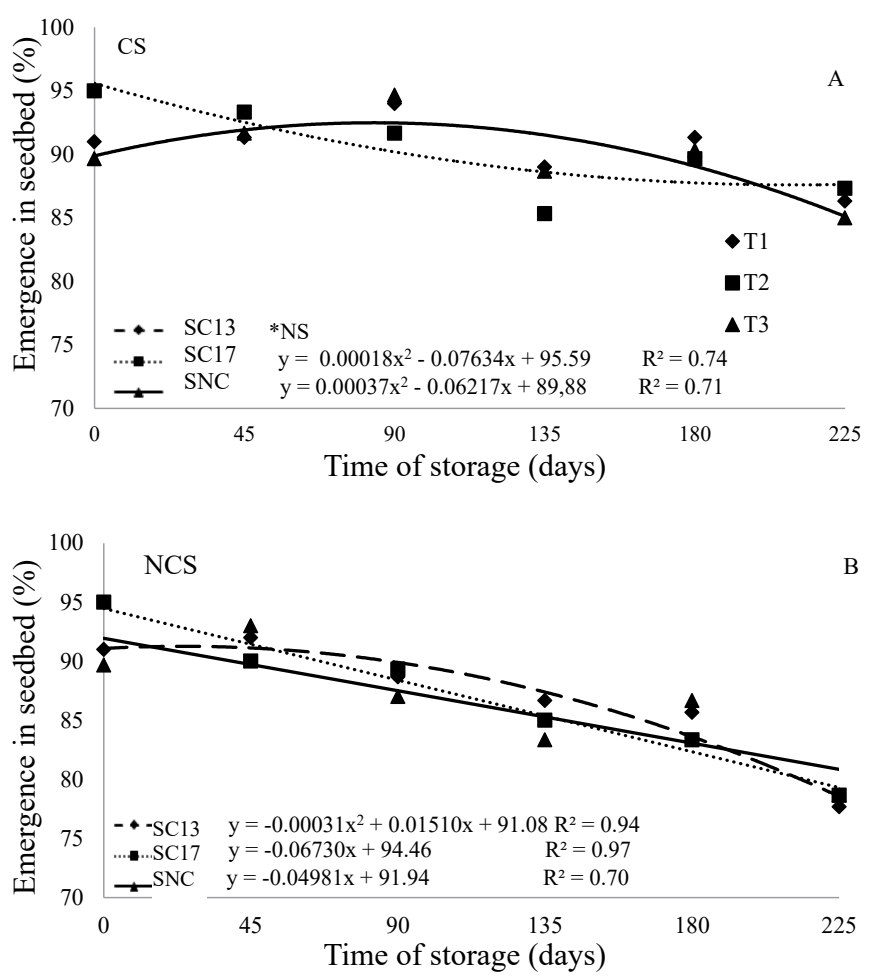

Figure 7. Emergence of seedlings in seedbeds (\%) throughout 225 days of storage in (A) cooled storage (CS) and (B) non-cooled storage (NCS). Seeds were submitted to dynamic cooling in three procedures: $\mathrm{SC} 13$ (seeds cooled at $13{ }^{\circ} \mathrm{C}$ at bagging), $\mathrm{SC} 17$ (seeds cooled at $17^{\circ} \mathrm{C}$ at bagging), and SNC (seeds not cooled at bagging). throughout the storage, respectively (Figure 7A).

In the NCS, both SC17 and SNC procedures had similar performances, represented by linear equations that expressed a reduction in vigor of approximately $12 \mathrm{pp}$ throughout the storage (Figure 7B). However, the seeds cooled at $13^{\circ} \mathrm{C}$ (SC13) maintained the quality for up to 90 days, approximately, and then suffered a decline expressed by a quadratic trend curve.

A comparison between the two warehouses showed that the variation was significant. Seeds kept in the refrigerated warehouse had smaller reductions in vigor than those stored in the NCS, i. e., the CS contributed to maintain the physiological quality of seeds, according to the emergence test in seedbed.

The use of high-vigor seeds provides benefits to soybean crops, such as taller plants, larger stem diameter, and up to $25 \%$ gain in grain yield in comparison to the use of low-vigor seeds (Schuch et al., 2009). Therefore, less vigorous seeds may reduce grain yield, and one of the possible causes may be associated with a greater emergence inequality. According to Cantarelli et al. (2015a) and Cantarelli et al., (2015b), late emergent plants are subject to a higher degree of intraspecific competition, which reflects in a decrease of production.

A general analysis of the results allows stating that the combination of cooling at bagging and maintenance of the refrigeration in the warehouse during the entire storage preserves successfully the quality of soybean seeds.

\section{Conclusions}

Artificial cooling at $13{ }^{\circ} \mathrm{C}$ at bagging, followed by storage in refrigerated warehouse at $20^{\circ} \mathrm{C}$, ensures the maintenance of soybean seeds physiological quality for 225 days. In nonrefrigerated storage, the soybean seeds submitted to dynamic cooling at $13{ }^{\circ} \mathrm{C}$ at bagging show higher vigor for 225 days, in comparison to those not cooled or cooled at $17{ }^{\circ} \mathrm{C}$. The refrigerated warehouse contributes to the physiological maintenance of soybean seeds, regardless of whether they are subjected to dynamic cooling or not.

\section{References}

BAUDET, L.; VILLELA, F.A. Armazenamento de Sementes. IN: PESKE, S. T.; VILLELA, F.A.; MENEGHELlO, G. E. (Ed.). Sementes: fundamentos científicos e tecnológicos. 3.ed. Pelotas: UFPEL, 2012. cap. 7, p. 482-527.

BRASIL. Ministério da Agricultura, Pecuária e Abastecimento. Regras para análise de sementes. Ministério da Agricultura, Pecuária e Abastecimento. Secretaria de Defesa Agropecuária. Brasília: MAPA/ACS, 2009. 395p. http://www.agricultura.gov.br/arq_editor/ file/2946_regras_analise_sementes.pdf 
CANTARELLI, L.D.; SCHUCH, L.O.B.; RUFINO, C.A.; TAVARES, L.C.; VIEIRA, J.F. Physiological seeds quality: spatial distribution and variability among soybean plant population. Bioscience Journal, v.31, n.2, p.344-351, 2015a. http://www.seer. ufu.br/index.php/biosciencejournal/article/view/22274/16108

CANTARELLI, L.D.; SCHUCH, L.O.B.; TAVARES, L.C.; RUFINO, C.A. Variabilidade de plantas de soja originadas de sementes de diferentes níveis de qualidade fisiológica. Acta Agronómica, v.64, n.3, p.234-238, 2015b. http://www.revistas.unal.edu.co/index.php/ acta_agronomica/article/view/45511/52118

CARDOSO, R.B.; BINOTTI, F.F. S.; CARDOSO, E.D. Potencial fisiológico de sementes de crambe em função de embalagens e armazenamento. Pesquisa Agropecuária Tropical, v.42, p.272-278, 2012. http://www.scielo.br/pdf/pat/v42n3/a04v42n3.pdf

CONAB - Companhia Nacional de Abastecimento. Acompanhamento da safra Brasileira. Grãos. v.3 - Safra 2015/16- n.4 - Quarto levantamento. |Janeiro, 2016. http://www.conab.gov.br/OlalaCMS/ uploads/arquivos/16_01_12_14_17_16_boletim_graos_ janeiro_2016.pdf

COSTA, N.P.; FRANÇA-NETO, J.B.; KRZYZANOWSKI, F.C.; HENNING, A.A. Metodologia alternativa para o teste de tetrazólio em semente de soja. EMBRAPA Soja- Londrina-PR, Série Sementes. Circular Técnica 39, 2007. 8p. http://www.cnpso.embrapa.br/ download/pdf/cirtec39_sementes.pdf

DEMITO, A.; AFONSO, A.D.L. Qualidade das sementes de soja resfriadas artificialmente. Engenharia na Agricultura, v.17, n.1, p.7-14, 2009. http://www.seer.ufv.br/seer/index.php/reveng/article/ viewFile/88/41
FORTI, V.A.; CICERO, S.M.; PINTO, T.L.F. Avaliação da evolução de danos por 'umidade' e redução do vigor em sementes de soja, cultivar TMG 113-RR, durante o armazenamento, utilizando imagens de raio X e testes de potencial fisiológico. Revista Brasileira de Sementes, v.32, p.123- 133, 2010. http://www.scielo.br/pdf/rbs/ v32n3/v32n3a14.pdf

HARRINGTON, J.F. Drying, storing, and packaging seeds to maintain germination and vigor. Proceedings Short Course Seedsmen, p.89-108, 1959.

SCHUCH, L.O.B.; KOLCHINSKY, E.M.; FINATTO, J. Qualidade fisiológica da semente e desempenho de plantas isoladas em soja. Revista Brasileira de Sementes, v.31, n.1, p.144-149, 2009. http:// www.scielo.br/pdf/rbs/v31n1/a16v31n1.pdf

SMANIOTTO, T.A.S.; RESENDE, O.; MARÇAL, K.A.F.; OLIVEIRA, D.E.C.; SIMON, G.A. Qualidade fisiológica das sementes de soja armazenadas em diferentes condições. Revista Brasileira de Engenharia Agrícola e Ambiental, v.18, n.4, p.446-453, 2014. http:// www.agriambi.com.br/revista/v18n04/v18n04a13.pdf

VILLELA, F.A.; MENEZES, N.L. O potencial de armazenamento de cada semente. Seed News, v.8, n.4, p.22-25, 2009. http://www. seednews.inf.br/html/site/content/reportagem_capa/imprimir. php?id=31

ZUCHI, J.; FRANÇA-NETO, J.B.; SEDIYAMA, C.S.; LACERDA FILHO, A.F.; REIS, M.S. Physiological quality of dynamically cooled and stored soybean seeds. Journal of Seed Science, v.35, p.353-360, 2013. http://www.scielo.br/pdf/jss/v35n3/12.pdf 